\title{
The Metamorphosis Project
}

\section{Ellis Nash Sr.}

$\mathrm{T}$

The Metamorphosis Project started after 11 September 2001, calling for

peace in prisons across the country as well as the streets of America, in honour of the all the men and women who lost their lives on that horrific, and most tragic day. Being a voice in the mid-west, I was asked to share my views on the matter of prison abuse. I am part of communities who are trying to find alternatives to solve problems without the use of gang mentality and violence.

One such community, located at (D.R.F.) Carson City Michigan Correctional Facility, apply the golden rule in a path of growth and development. This group was founded by David Boxdale and overseen by Larry Hoover, with its home base on the Southside of Chicago. Brothers of the Same Struggle (BOSS) and other similar groups vow to educate their communities in the ways of growth and development, on how to identify prison abuse and how to report it without retaliation by staff or other prisoners.

The recent increases in discretionary power and consequent abuses by prison staff is largely a result of legislative and judicial decisions that have eroded the hard won, but short lived reforms of the 1960s, 1970s and 1980s. No one in any society has less power than the people who are held behind bars. The very nature of incarceration creates events that support the abuse of prisoners. Throw in the race issue, which is a factor which cannot be ignored in today's correctional context, and the element of abuse becomes even more endemic. What distinguishes prison systems throughout the world is the degree to which prisoners are dehumanized and segregated from the citizenry, and the level of prison staff and its 'official' discretion or, conversely, the degree to which the oversight of what occurs behind prison walls is overlooked by politicians, judiciary, branches of government, and members of both the press and public.

In America, organizations such as the American Friends of Service Committee, the American Civil Liberties Union, Human Rights Watch and Amnesty International, have all attempted (sometimes with success) to influence policy and practices regarding prisoner's rights. Historically, prisoners in America were viewed as slaves of the state. The Thirteenth Amendment specifically exempts prisoners. The Amendment provides neither slavery nor involuntary servitude, except as punishment for crime. Thus, although this country was hypothetically founded on a belief in, and 
a commitment to, individual's rights and freedoms, the Bill of Rights has only applied to prisoners for the past forty years. In the wake of the civil rights and prison movements, and utilizing an expanded concept of human rights, the Supreme Court began to treat prisoners as citizens and not slaves.

Beginning in the late 1960s, a series of court decisions outlined prisoner's rights and established standards for prison conditions and for the treatment and care of prisoners. In 1974, the Supreme Court held that, though his other rights may be diminished by the needs and exigencies of the institutional environment, a prisoner is not wholly stripped of Constitutional protections when he or she is imprisoned for crime. There is no Iron Curtain drawn between the Constitution and the prisons of this country. The Arkansas prison system was the first to come under Federal judicial scrutiny. Quickly prohibited were the long standing practices of whipping prisoners with large leather straps and using the 'Tucker Telephone' to administer electric shocks to a prisoner's body. On appeal, the Eighth Circuit prohibited all forms of corporal punishment.

The present goal of the Metamorphosis Project is to verify that, before recent development of Federal judicial oversight of our prisons, a reign of terror existed in many prisons in this country. This terror was recounted in films such as Murder One - the story of Alcatraz's dungeons and the people who were held in them for years, without any contact with the outside world. Brubaker is about Angola, the Louisiana state prison and the bodies buried beneath its walls. The film also presented a litany of abuses, ranging from the merely disturbing to the utterly shocking. Court after court uncovered evidence of system-wide abuse, and began ordering extensive injunctive relief. Although judicial intervention and oversight succeeded in limiting some of the more serious violations of prisoner's civil and human rights, only some of those whose rights were violated were compensated. Under this intervention they were never able to completely eliminate or prevent either individual or systemic abuse of prisoners.

This paper is not an argument for judicial oversight as the solution to the problem of prison abuse, but rather is an indictment of the prison system itself. However, I do advocate for more extensive court intervention to prevent a return to those conditions of the past. Civil rights litigation, brought either by pro se prisoners' litigations or by public interest lawyers, can have a dramatically beneficial effect on correctional institutions. However, litigation will never eliminate prison abuse, nor fundamentally change the 
nature of incarceration. At best, judicial intervention limits prison abuses, but never provides sufficient principled guidance or adequate means of enforcement to prevent such abuse. It is within the context of endemic and systematic abuse that external oversight becomes the key predictor of the extent of prison abuse. Thus, it is no coincidence that as judicial oversight over prisons has been limited, we have witnessed an increase in the level of abuse in prisons.

Twenty-eight years ago after Attica, riots and rebellions are no longer front-page news. They are routine. Little is known about these rebellions because prison authorities, learning perhaps from the Attica experience, now keep the media away. In Virginia, California, Michigan and other states, reporters are now banned from routine interviews with prisoners. In 1999 alone there were significant disturbances in prisons in eight states. In New York, prisoners in Sing Sing and Green Haven spent two weeks before the Attica settlement locked in their cells for twenty-four hours a day, as prison officials reacted to a nonviolent demonstration of collective distress with parole inaction. These prisoners wore only prison clothing for several days, and had remained silent outside their cells.

External oversight of what occurs behind prison walls increasingly has come from sources other than our courts. As the courthouse doors have been closed to prisoners, segments of civil society, including academic leaders in the communities from which prisoners come from and to which they will return, as well as families and friends of those incarcerated are attempting to exert a greater impact upon what goes on behind those walls. Human rights organizations, such as Amnesty International and Human Rights Watch have launched investigations into the brutality and abuse in American prisons. They are demanding that prisons in the U.S. conform to institutional human rights standards. Now that prisoners in U.S. have lost many of their civil rights, or at least the means of enforcing those rights, protection of their universal human rights is of vital importance.

Every year, the Human Rights Committee of the United Nations reviews complaints brought before it and finds that some parties have violated the International Covenant on Civil and Political Rights by allowing, among other things, ill treatment of prisoners and inhumane prison conditions. Article 53 of the Covenant protects such rights as the right to life, liberty and security of person, and prohibits torture, slavery and forced labour. Among the remedies imposed are compensation and commutation of 
sentence. If, however, we remain unable to eliminate what we all agree is ethically unacceptable behaviour, then it is time to re-evaluate the prison system as we know it.

A voice for individuals across the country who cannot speak for themselves, the Metamorphosis Project is part of the non-violence movement to help rebuild the love of community and family.

\section{ABOUT THE AUTHOR}

Born in Arkansas and raised on the streets of Chicago, Ellis Nash Sr. graduated from Lakeland College. Ellis also attended Wayne State College. A special thanks goes to his parents and to his youngest sister for all her support. He works tirelessly to stop abuse in prison. 